\title{
A presença indígenana Vila Real do Senhor Bom Jesus do cuiabá e seu termo
}

\author{
Loiva Canova*
}

A proposta deste texto é dissertar sobre a historicidade da Vila Real do Senhor Bom Jesus do Cuiabá no setecentos, localizada no centro da América do Sul. Vila que resultou da concentração populacional de índios, escravos negros africanos, europeus e mamelucos, bem como dos processos históricos da expansão dos bandeirantes, das monções, do sonho do ouro, da caça aos índios e das estratégias geopolíticas de colonização do império português. $\mathrm{O}$ objetivo deste artigo é dar visibilidade à presença indígena na Vila e no seu termo por meio da documentação local produzida pelos agentes do governo português.

Palavras-chave: Cuiabá; índios; colonização.

The purpose of this text is to speak about the historicity of Vila Real do Senhor Bom Jesus do Cuiabá seven hundred, located in the center of South America that resulted from the village population concentration of Indians, slaves, Africans, Europeans and mestizos as well as processes Historic expansion of the pioneers, the monsoons, the dream of gold, the Indians

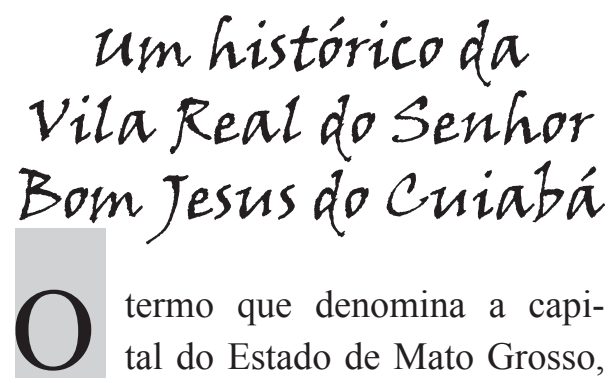
Cuiabá, é uma expressão urbana que resultou das ações expansionistas dos bandeirantes paulistas. A Vila do Cuiabá tem mais de três séculos de história, o período da história colonial. Sua trajetória está registrada ainda nos tempos das viagens monçoeiras, do sonho do ouro e da caça aos índios, cuja mão de obra muito serviu à agricultura em terras de São Paulo.

\footnotetext{
* Doutora em História, Professora do Departamento de História da UFMT. loivacanova@gmail.com
} 
hunting and geopolitical strategies of colonization of the Portuguese empire. The purpose of this article is to give visibility to the indigenous presence in the village and its end through the documentation produced by the local agents of the Portuguese government.

Keywords: Cuiabá; indians; colonization.

Atualmente, Cuiabá limita-se com os municípios de Chapada dos Guimarães, Campo Verde, Santo Antônio do Leverger, Várzea Grande, Jangada e Acorizal. $\mathrm{O}$ município, banhado por intensos raios solares, está situado às margens do rio homônimo e forma uma conturbação urbana com a cidade de Várzea Grande. A estatística populacional dos dois municípios soma a média de 750 mil habitantes.

Inicialmente, foi chamada pelos oficiais da Coroa portuguesa de Vila Real do Senhor Bom Jesus do Cuiabá e ganhou essa condição ainda no início dos anos vinte do setecentos, precisamente em primeiro de janeiro de 1727.

Nos anos de 1718 e 1719, antecedendo a condição de vila, as tão famosas minas eram administradas por seu descobridor e fundador, Pascoal Moreira Cabral. Ele era o chefe da bandeira que chegou às paragens do Rio Cuiabá, afluente do Rio Paraguai, com o intuito de apresar índios Coxiponés. Ali se estabeleceu por resultado da significativa descoberta de ouro no Rio Coxipó, onde foi formado o primeiro núcleo populacional, o Arraial da Forquilha.

Em pouco tempo, seguindo para a região das minas do Cuiabá, muitos homens chegaram com Rodrigo Cesar de Menezes, o governador de São Paulo, para dar início às práticas de colonização. Foi nessa época em que ocorreu o processo histórico do expansionismo português, na sua margem mais dilatada, a oeste do antigo Tratado de Tordesilhas, um sertão ainda pouco conhecido pelos oficiais da Coroa portuguesa, de onde, mais tarde, viria o primeiro governador da capitania de Mato Grosso, Antônio Rolim de Moura.

A espacialidade da conquista e colonização portuguesa do arraial ficaria inicialmente sob a administração da Capitania de São Paulo, posteriormente desmembrada para ser criada a Capitania de Mato Grosso, no ano de 1748.

O Capitão-General e Governador da Capitania de São Paulo, Rodrigo Cesar de Menezes, viajou com monçoeiros em direção ao arraial do Cuiabá, chegando 
às minas em 1726. Foi responsável por elevar o arraial à categoria de Vila, e nela administrou a Câmara. Nas obrigações reconhecidamente públicas, o Capitão-General da Capitania de São Paulo oficializou a conquista na parte mais central da América do Sul. ${ }^{1}$ As ações de Rodrigo Cesar de Menezes significaram o símbolo da rígida administração metropolitana, sentida, sobretudo, na região das minas novas. Nelas estabelece o fisco, aparelha a burocracia, levanta Pelourinho, toma casas para Senado da Câmara e nomeia Ouvidor. ${ }^{2}$

Conforme define Carlos Alberto Rosa, as "câmaras eram instituições locais, que tiveram papel fundamental na formação e manutenção da América portuguesa". Ao iniciar a colonização do Cuiabá, nas primeiras décadas do setecentos, Portugal havia acumulado experiência na colonização imperial em três continentes, consolidando a instituição urbana das câmaras em séculos de domínio ultramarino. ${ }^{3}$

Rosa explica que a câmara do Cuiabá

normatizava o espaço urbano, o fornecimento de gêneros alimentícios a moradores da vila, o exercício de "ofícios mecânicos" na vila e seu termo por meio de "exames de Mestres de Ofícios", a saúde contratando cirurgiões para atender as camadas mais pobres do "povo" e "seus escravos", [...] a concessão de terras sesmarias. ${ }^{4}$

Ainda segundo Rosa, nas câmaras eram elaborados estatutos e posturas municipais que normatizavam questões de edificação, higiene, saúde, alimentação e festas, entre outros. Havia concessão de privilégios e imunidades aos "homens da governança" (vereadores, juízes, oficiais camarários), concedendo-lhes que praticassem com a isenção possível o "bem comum". 5

É possível confirmar nos registros deixados por Rodrigo Cesar de Menezes que, em um esforço para fundar a Vila Real do Bom Jesus do Cuiabá, no ano de

${ }^{1}$ MENDONÇA, Rubens. História de Mato Grosso. Cuiabá: Fundação Cultural de Mato Grosso, 1982. p. 67 e ss.

${ }^{2}$ CORRÊA FILHO, Virgílio. História de Mato Grosso. Rio de Janeiro: INL, 1969. p. 205.

${ }^{3}$ ROSA, Carlos Alberto. Mínima história dos Anais. In: ANNAES do Sennado da Camara do Cuyabá: 1719-1830. Transcrição e organização Yumiko Takamoto Suzuki. Cuiabá: Entrelinhas; Arquivo Público de Mato Grosso (APMT), 2007. p. 21.

${ }^{4}$ Idem, p. 23.

${ }^{5}$ Ibidem, p. 22. 
1726, aplicou todo "cuidado, indústria, e com despesas", e de seus soldos investiu na vinda de "muitos moradores" para, nas terras com abundância de ouro e índios, produzirem mantimentos. Porque muito precisava ser alargada a fronteira naqueles "desertos indecisos pela linha imaginária". A Vila Real do Senhor Bom Jesus do Cuiabá foi descrita pelo capitão, em 1732, como a de "mais larga extensão do domínio da Coroa", cuja localização, conforme escrevia, ficava "no mais interior de todo o estado do Brasil". ${ }^{6}$ As representações, elaboradas em meados da terceira década do setecentos, sobre as minas do Cuiabá, no interior do sertão, foram configuradas com múltiplos sentidos, cuja dimensão fica evidente nos vocábulos escolhidos para a descrição: "larga extensão", "desertos", "dilatadas jornadas" e "dilatadas campinas". ${ }^{7}$

Segundo Virgílio Corrêa Filho, só na monção de 1726, em que viajou Rodrigo Cesar de Menezes, chegaram ao porto do Rio Cuiabá cerca de 3 mil pessoas, entre negros e brancos, em um comboio com mais de 300 canoas. ${ }^{8}$ Apesar de a viagem até as minas de Cuiabá ser, sem dúvida, perigosa, muitas vezes, mesmo em meio às dificuldades, mostrou-se prazerosa e exótica. $\mathrm{O}$ inédito da flora e fauna tem destaque nos relatos sertanistas. Os monçoeiros encaravam todo tipo de obstáculos: corredeiras, doenças, fome, frio, calor, cansaço, mosquitos e ataques indígenas. O flagelo considerado mais terrível era o enfretamento com os ferozes índios Paiaguá, cujos ataques tiveram início em $1725 .{ }^{9}$

A população de São Paulo, porém, não desistiu. Muitas pessoas se dirigiram às novas minas, e por elas andaram, viveram, exploraram minério, esquadrinharam suas riquezas nas margens dos córregos, sendo o mais famoso o da Prainha, afluente à esquerda do Rio Cuiabá. Ali, o bandeirante sorocabano Miguel Sutil descobriu a mais rica das minas coloniais. Outros encontraram ouro, próximo de onde é hoje a Igreja do Rosário. Esses achados minerais marcariam definitivamente um dos lugares da colonização.

\footnotetext{
${ }^{6}$ PARECER do Conselho Ultramarino enviado por Rodrigo Cesar de Menezes. Lisboa Ocidental, 8 jan. 1732. Núcleo de Documentação e Informação Histórica Regional - NDIHR (UFMT), microficha 6 , doc. $80 /$ AHU.

${ }^{7}$ GALETTI, Lylia da Silva Guedes. Nos confins da civilização: sertão, fronteira e identidade nas representações sobre Mato Grosso. 2000. Tese (Doutorado em História) - Faculdade de Filosofia, Letras e Ciências Humanas, Universidade de São Paulo, São Paulo, 2000. p. 23 e ss.

${ }^{8}$ CORREAA FILHO, V. Op. cit., p. 50.

${ }^{9}$ HOLANDA, Sérgio Buarque de. Monções. São Paulo: Brasiliense, 2000. p. 64.
} 
Com as descobertas do ouro, esse lugar tão distante foi devidamente repovoado por pessoas de várias localidades. Além daquelas vindas de São Paulo, vieram também de Minas, as das Gerais e dos Goiases. Na primeira Vila, na margem mais a oeste de todas as terras da América portuguesa, homens e mulheres trataram de aparelhar o lugar com práticas de produção agrícola, criações e vários outros afazeres característicos de um cotidiano de vida urbana. Construíram casas, quintais e levantaram capela usando madeira, barro, taipa de pilão e alvenaria, material utilizado pela população moradora da Vila. Segundo Holanda, no ano de 1727 havia ali 2,6 mil negros e índios labutando nas lavras de ouro. ${ }^{10}$

Essa espacialidade logo mostrou indícios de crescimento. Por meio dos registros, segundo Carlos Alberto Rosa, observa-se a movimentação dos "carros de boi transportando carga entre a vila e o porto geral" e as edificações construídas em forma de "sobrado", confirmam a consolidação do centro da vila e a ostentação do poder. ${ }^{11}$

A propósito dos primeiros ranchos, o arquiteto Júlio de Lamonica Freire escreveu que foram erguidos sem preocupações urbanísticas e localizavam-se nas cercanias das lavras, onde os moradores aproveitavam "os espaços livres das encostas escavadas pela garimpagem do ouro. Ruas e ruelas serpenteavam pelo terreno, ajustando-se a ele, ao longo do curso d'água”. Segundo Freire, a produção do espaço urbano foi consequência da expressão arquitetônica do barroco. A matriz, o pelourinho, as igrejas do Senhor dos Passos e do Rosário foram os primeiros "pontos de tensão em torno dos quais a vila se estruturava e se organizava”. Em torno das áreas das jazidas, principalmente nas da margem esquerda do riacho, em frente à colina, iniciou-se o povoamento, erguendo-se a Matriz, as igrejas, os largos, as primeiras ruas, as primeiras casas. ${ }^{12}$

Cuiabá simbolizou, no setecentos, um espaço de conquista, um minúsculo fragmento das intencionalidades do projeto colonial português. Nela, se concentraram os mais diferentes personagens da colonização, entre eles os admi-

\footnotetext{
${ }^{10}$ Idem, p. 55.

${ }^{11}$ ROSA, Carlos Alberto. A Vila Real do Senhor Bom Jesus do Cuiabá (vida urbana em Mato Grosso no século XVIII: 1722-1808). 1996. Tese (Doutorado em História), Faculdade de Filosofia, Letras e Ciências Humanas, Universidade de São Paulo, São Paulo, 1996. p. 63 e ss.

${ }^{12}$ FREIRE, Júlio de Lamonica. Por uma poética popular da arquitetura. Cuiabá: EdUFMT, 1997. p. 40 e 42 .
} 
nistradores coloniais, representantes do poder metropolitano, que compunham o quadro dos agentes oficiais do comando da conquista, responsáveis, respectivamente, pela execução do conhecimento e reconhecimento do espaço, pela pregação da fé em Cristo e, também, pela defesa do território.

Inicialmente um modesto povoado, posteriormente tornou-se arraial, vila e então cidade, condição à qual passou em 17 de setembro de 1818. Atualmente a maior de todas as cidades que agregam o conjunto das expressões urbanas do Estado de Mato Grosso, Cuiabá é uma cidade que traz em sua história 293 anos de movimento arquitetônico, em um espaço de cerrado, cortada por vários córregos e pelo Rio Cuiabá, por onde chegaram os monçoeiros com seus inúmeros sonhos de riqueza.

Cuiabá foi lugar que teve em prospectos suas linhas e curvas e, nas construções dos equipamentos da vila, o esforço conjunto de muitos trabalhadores. $\mathrm{O}$ trabalho indígena foi na maior parte dos Bororo, Paresi, Guató, Paiaguá, Guaná, Mizuaré e dos negros africanos escravizados e forros. ${ }^{13}$

Os africanos e seus descendentes foram trazidos para o Cuiabá desde as primeiras décadas do setecentos. Sobre os africanos, escreveu Carlos Alberto Rosa: "Há vários casos de senhores trazendo 14 a 28 escravos cada um, antes de 1727. Só em 1726 entraram na freguesia do Cuiabá 373 escravos", ${ }^{14}$ e complementa: "A presença africana aqui evoca as intensas relações entre a América e a África. E os elos do tráfico, litoral atlântico e esta parte, articulando África ocidental, Bahia, Rio, São Paulo e Minas Gerais ao Cuiabá". ${ }^{15}$

$\mathrm{Na}$ sociedade colonial, desigual, hierárquica, preconceituosa, os negros e também os índios bravios (os indivíduos mais desqualificados de toda a sociedade da época) - portanto, infiéis - foram reiteradamente representados como perigosos e traiçoeiros pelos oficiais da Coroa portuguesa, sobretudo no contexto de expansão e colonização, porque impediam, atrasavam e oneravam os investimentos do império luso na parte da conquista mais dilatada de todas as terras

${ }^{13}$ ROSA, Carlos Alberto. O urbano colonial na terra da conquista. In: ROSA, Carlos Alberto; JESUS, Nauk Maria de (Org.). A terra da conquista: história de Mato Grosso colonial. Cuiabá: Adriana, 2003. p. 23-24.

${ }^{14}$ Idem, p. 38.

${ }^{15}$ Idem, p. 38. 
da colônia americana. A presença de africanos escravizados foi relatada na correspondência oficial, nas crônicas e nos relatos sertanistas do período. Para este texto, destaca-se um fragmento de documento que menciona ataques de índios da nação Bororo a africanos escravizados:

Táobem na Chapada deráo os Bororos na ultima outava de Pascoa onde matarão hua negra, e frecharáo dous negros. Sahiráo duas Bandeiras para este Certáo permita Deos se estinguáo estes venenozos bixos que tanto vão danificando este Paiz e impossibilitando as conveniências a seus habitantes. ${ }^{16}$

Os negros estavam na lida dos ofícios urbanos e nos trabalhos da roça. $\mathrm{O}$ número de negros no ofício dos engenhos de aguardente e do melado de cana-de-açúcar era significativo:

E na verdade Senhor ao que me parece servem mais os sobreditos Engenhos de ruína a estas Minas de que de utilidade a S. Magestade q. Deos Guarde porque havendo nellas dezassete ou dezoito Engenhos, e mais alguns e acarossadores [?] em que se fabricáo mellados e agoardente em cujas fabricas se acháo ocupados milhor de quatrocentos negros, $[\ldots] .{ }^{17}$

Para além dos conteúdos registrados por meio de mandos e notícias, com problemáticas amplamente diferenciadas em um fragmento textual, a Vila foi cenário cujo principal meio de articulação era a igreja, denominada Bom Jesus, o mais importante ponto de referência por onde delineavam-se os contornos de ruas. Dimensão estratégica de fluxos e refluxos, a igreja foi símbolo demarcador dos novos empreendimentos da ação dos diferentes moradores da Vila. Segundo Carlos Alberto Rosa, a igreja do Bom Jesus, feita pelo sorocabano Jacinto Barbosa Lopes, que construíra também a matriz da Vila do Carmo, nas Gerais ${ }^{18}$, foi o marco inicial do arraial.

${ }^{16}$ CÓPIA DE CARTA escrita ao Excelentíssimo Senhor Conde e General pelo Provedor da Fazenda Real das minas do Cuyaba, Thomé de Gouvea e Saâ Queiroga. Villa Real do Senhor Bom Jesus do Cuyabâ, 7 jun. 1734. Núcleo de Documentação e Informação Histórica Regional - NDIHR (UFMT), microficha 28, doc. 1092/AHU. In: MORGADO, Eliane Maria de Oliveira et al. (Org.). Coletânea de documentos raros do periodo colonial (1727-1746). Cuiabá: EdUFMT, 2007. (Série transcrição: correspondência, v. 2), p. 56. A transcrição de aproximadamente 225 documentos ibéricos integrais, avulsos selecionados que compõem a série correspondências, dividida em quatro volumes, foi realizada por Otávio Canavarros, professor Doutor do Departamento de História da Universidade Federal de Mato Grosso (UFMT).

${ }^{17}$ Idem, p. 57.

${ }^{18}$ Para compreender em detalhes a história da constituição da Vila Real do Senhor Bom Jesus do Cuiabá e de seus moradores, ver ROSA, 1996 e ROSA, 2003. 
Simultaneamente, autoridades portuguesas definiram como deveria ser o espaço do arraial. Sua elevação à categoria de vila deu-se em 1727, com governo local autônomo, que evidenciava a "governança" da vila sobre o vasto território. ${ }^{19}$

A partir da instalação da igreja Bom Jesus, foram construídos os primeiros arruamentos, os primeiros becos, que se insinuavam em suas curvas. Serviram aos que seguiam mais apressados e, a passos largos, precisavam encurtar o trajeto diário.

As fontes de água potável também compunham o cenário do ambiente da Vila. Recebiam especial atenção, tanto que, para elas, foram construídos ranchos e demais coberturas. Na Vila, havia água em lugares como o "sítio da paragem", o da "Mandioca", atual Praça do Conde de Azambuja, o "Tanque do Ernesto" e mais três fontes na margem oriental da Prainha, avenida que atualmente corta o centro da cidade. ${ }^{20}$

A água potável era transportada pelos escravos africanos e indígenas, os "negros da terra". Esses homens também trabalhavam nos serviços das roças, da extração do minério, nas olarias, no fabrico das telhas e dos tijolos, nas vendas, na criação de gado vacum e cavalar, na pescaria e nas benzeções e curas.

Conforme afirmou o historiador Edvaldo de Assis, as pessoas no Cuiabá, em muitas ocasiões, substituíram o conhecimento científico pelo saber do povo. Muitos usavam de alguma garrafada para o trato de enfermidades e, por vezes, contavam com os serviços de sangradores e de cirurgiões, além dos das irmandades religiosas, que em alguns momentos de desamparo se prestavam à solidariedade, "como, por exemplo, por ocasião dos sepultamentos e em caso de alguma condenação à forca". A população pobre usava de "curandeiros, das rezas, das benzeduras e de plantas medicinais como a erva de bicho, a quina, angico, poaia, barbatimão, erva-de-santa-maria, picão, caroba, erva-de-santo-inácio, água-pé". ${ }^{21}$

As informações pesquisadas por Assis a respeito do uso medicinal de ervas pela população pobre são confirmadas pelo Governador de São Paulo, nos anos trinta do setecentos.

Quanto ao sirurgáo, e botica, se faz desnecessario, porq. naquelle Certáo, e ainda nas mesmas Minnas se curáo infermidades graves com o remedio de ervas,

\footnotetext{
${ }^{19}$ Idem, 2003, p. 15.

${ }^{20}$ Idem, 1996, p. 28.
}

${ }^{21}$ ASSIS, Edvaldo de. Cuiabá colonial: povoamento e sociedade. Cuiabá: Barros, 1988. p. 60 e 63. 
e balcemos de arvores como experimentey padecendo hua opilaçáo, procedida de roins mantimentos, e aguas, e depois cuberto de lepara [?] q. me durou seis mezes, sem ficarme libre mais parte do corpo, q. o rosto. Cujas enfermidades destroiráo [?] os remedios daquelles certóes, o que não fariáo, os exquezitos das boticas. ${ }^{22}$

Os pobres da Vila do Cuiabá tinham seus pequenos roçados e criatórios de porcos, portanto, estavam garantidos os rendimentos provenientes da venda de carne e do toucinho, bastante consumidos pela população. Nas roças, eram produzidos arroz, milho, abóbora e feijão e havia homens que trabalhavam na curtição do couro e nos engenhos de cana-de-açúcar e aguardente. Alguns também se ocupavam da atividade pesqueira, aproveitando-se do rio e das práticas indígenas, como o uso do timbó, da flecha e das iscas de genipapo. O peixe era o principal alimento da população pobre da vila, e o excedente era utilizado na fabricação de óleo ou vendido, pois era usado na iluminação das casas. ${ }^{23}$

Para os mais afortunados, era possível adquirir no comércio da Vila, segundo um atestado no qual está registrada uma relação de produtos e preços, os seguintes itens:

Atestamos Que os preços dos Viverez que prezentemente Correm nestas Minas do Cuyaba tanto do que produz a terra das mesmas Minas como os que Vem de fora, São os Seguintez a Saber, Carne de Vaca a oitava e quarto arouba, Carne de Porco fresca a oitenta reis de ouro a libra, Toucinho Salgado a Cento e Vinte reis de Ouro a Libra, o alqueire de milho a tres quartos de Ouro o alqueire, o alqueire de feijão a oitava e meya, o alqueire de Farinha tanto do milho como da mandioca a oitava e meya, o alqueire de [ileg. + - 2 pal.] oitavas, huma Galinha meya oitava de ouro, hum frango meya pataca[?] de Ouro, hum [ileg. +-4 pal.] tres quartos [ileg. +-2 pal.] viveres da terra, e os que [ileg. +-2 linhas] [f. 9]. O Frasco de Vinagre oitava e meya, Frasco de Aguardente do Reyno oitava e meya, o Frasco de Vinho duas oitavas, Manteiga a Libra a doze Vintens de Ouro, Farinha do Reyno a libra a meya pataca de Ouro, Pão o mais pequeno a oitenta reis de Ouro, Barril de Sal[?] de Alqueire a dez oitavas de Ouro, ASucar a libra a doze Vintens de Ouro, Cujos preços dos Sobreditos

\footnotetext{
22 PARECER do Conselho Ultramarino enviado por Rodrigo Cesar de Menezes. Lisboa Ocidental, 2 fev. 1732. Núcleo de Documentação e Informação Histórica Regional - NDIHR (UFMT), microficha 10, doc. 692/AHU. In: MORGADO, Eliane Maria de Oliveira et al. (Org.). Coletânea de documentos raros do periodo colonial (1727-1746). Cuiabá: EdUFMT, 2007. (Série transcrição: correspondência, v. 1), p. 82-83.
}

${ }^{23}$ ASSIS, Edvaldo de. Op. cit., p. 58. 
Generos algúas vezes tem deminuição, e outras vezes mayoria, Conforme a abundancia delles, e a mora que há das [ileg.] dos Povoados a estas Minas, donde Se experimenta falta de $m .{ }^{\text {tos }}$ dos Sobreditos generoz, e os q' há Sobem a preço mais avultado do que esta exposto, Sendo o Commum preço O que aSsima Se rellata de Cada genero. E por nos Ser pedida a prezente atestacão pelos Supplicantes declarados em a petição Verso lha mandamoz passar, o que tudo nella exposto Certeficamoz Ser Verdade, e para que [ileg.] haja de dar inteira [ileg. + - 3 linhas] [f. 9v]..$^{24}$

A população pobre da Vila do Cuiabá sofria ações de agentes do Estado português, que oprimia e aplicava severos castigos com a finalidade de garantir o sistema escravocrata e a ordem pública. As violências contra a população carente em Cuiabá eram comuns, sendo as mais contumazes as prisões e as condenações ao enforcamento. Homens necessitados eram aproveitados para o serviço das vilas e, muitas vezes, incorporados como soldados nas companhias militares, com a garantia de um parco salário. Algumas companhias, inclusive, como a de Ordenança, pagavam os soldados com o que era chamado de "munição de boca", ou seja, os soldados trocavam serviços por alimentos. ${ }^{25}$

A formação social na vila Real do Cuiabá teve como consequência a intranquilidade e a violência nas ruas, especialmente por ocasião das festas religiosas e profanas, que mobilizava pessoas de todas as condições sociais. A sociedade da Vila do Cuiabá carecia de oportunidades para homens pobres, e estes, muitas vezes, "cometiam roubos, crimes e outros tipos de violência". Era comum o poder público aproveitar-se desses "desocupados para o serviço militar, ou como componentes das bandeiras que saíam à caça de índios e de quilombolas ou escravos fugidos". ${ }^{26}$

Na Vila Real do Cuiabá, para atender à demanda de atividades mais especializadas, havia pessoas capacitadas para exercer ofícios de mecânicos ou

${ }^{24}$ REPRESENTAÇÃO dos oficiais Vitoriano Freitas da Cunha, Felix Caetano Pimentel Coelho, Maurício José de Abreu, Manoel da Ponte Pedreira e Francisco Xavier Dorta Tejo e os soldados de Dragões da Capitania de Mato Grosso ao [secretário de estado da Marinha e Ultramar] Diogo de Mendonça da Corte Real em que pedem que os seus soldos sejam pagos de mil réis por oitava de ouro desde o dia em que assentaram praça. Vila do Cuiabá, 27 abr. 1751. Arquivo Histórico Ultramarino, Mato Grosso, Projeto Resgate, Caixa 5, doc. n. 342.

${ }^{25}$ ASSIS, Edvaldo de. Op. cit., p. 58-60.

${ }^{26}$ Idem, p. 33 e 59. 
artesãos, como sapateiros, alfaiates, pedreiros, seleiros, carpinteiros, barbeiros, oleiros, pintores, caldeireiros e músicos, além de outros tipos de prestação de serviços à comunidade. ${ }^{27}$

Ofícios e espaços foram multiplicados. A população foi aumentando, o cenário da vila mudou. O Mundéu, o Porto, o Coxipó, a Matriz e o Oratório eram pequeninos focos de adensamento edificado, ligados entre si por caminhos, ruas e travessas, que iam do centro da Vila para o Porto, para o Coxipó, para as lavras da Conceição e do Jacé e, a partir de 1737, para "os Goiases".

Todas as ruas seguiam o eixo norte-sul em direção à Prainha, na época, ligada por travessas e becos perpendiculares, raras vezes oblíquos. Com o tempo, mais obras, manutenções, ruas e casas foram feitas. O cenário da incipiente Vila foi gradativamente ganhando proporções, projeções e materialidade. As ruas foram alargadas, ocorrendo em algumas vezes os pontos de fuga. Na Vila Real do Bom Jesus do Cuiabá, as leis de ordenamento colonial foram aplicadas, sistematizando condutas em relação aos mais variados assuntos. As casas, de acordo com algumas diretrizes, ganharam simetria, as janelas, portas e muros eram construídos em conformidade com as orientações da municipalidade portuguesa.

A Vila foi ponto de expressão administrativa que permitiu a produção da memória, no lugar da Câmara Municipal, ponto máximo da expressão do poder, onde os oficiais da Coroa deixaram registrados seus valores, intenções e condutas. Foi na Vila Real do Senhor Bom Jesus do Cuiabá, minúsculo território do projeto colonial português, que se edificou o agenciamento do colonialismo metropolitano, no descobrimento das novas minas e identificação toponímica.

O Rio Cuiabá, naquele tempo em que a procura do ouro e a caça aos negros da terra era atividade importante, representou um dos principais lugares de chegada de comerciantes, funcionários reais, gente de vários tipos e sertanistas monçoeiros. Os rios, nos idos setecentistas, foram transformados em caminhos "os caminhos que andam". ${ }^{28}$ O Rio Cuiabá, com toda a sua carga histórica, "com suas rochas memórias", representou o ponto do afluxo na Vila de invocação real,

${ }^{27}$ Idem, p. 58.

${ }^{28}$ HOLANDA, Sergio Buarque de. Op. cit., p. 18. 
divina e ameríndia. Atualmente, a história do rio se faz pela atuação de moradores de dois centros urbanos, cruzado por pontes que ligam as cidades de Cuiabá e Várzea Grande e, a exemplo de outras, o rio de tantas "marcas" não tem merecido, nem da população local, nem de seus administradores, o devido cuidado com os seus recursos naturais, preciosos à vida e ao planeta. ${ }^{29} \mathrm{Em}$ momento oportuno, em que indivíduos de diversos setores, ONGs, sociedades indígenas e ambientalistas mostram-se ocupados com os impactos ambientais, finaliza-se esse item com as seguintes palavras:

Os recursos hídricos são essenciais para a vida no planeta, estando a sobrevivência dos homens, animais e plantas dependente desse recurso natural. A disponibilidade de água para o consumo humano deve ser uma preocupação constante da humanidade, pois a crescente demanda, oriunda do crescimento populacional e das atividades econômicas, diminui a disponibilidade desse recurso natural, comprometendo o abastecimento humano e a produção de alimentos. Os cursos de água são vitais e de importância estratégica para suas regiões. Ao inundar periodicamente as suas margens, fertilizam o solo para o cultivo agrícola; são fontes de abastecimento de água doce e de alimentos para a população [...]. ${ }^{30}$

\section{A presença dos indios na
vilado cuiabá e seu termo}

Sobre a presença dos índios no termo da Vila ${ }^{31}$, Carlos Alberto Rosa explicou que houve muito trabalho compulsório, inclusive em lavras. Desses, destacou

\footnotetext{
${ }^{29}$ Para tal discussão ler: SCHAMA, Simon. Paisagem e memória. São Paulo: Companhia das Letras, 1996. "A natureza selvagem não demarca a si mesma, não se nomeia. [...] Embora se reconheça (como se deve) que o impacto da humanidade sobre a ecologia da terra não foi puro benefício, a longa relação entre natureza e cultura tampouco tem constituído uma calamidade irremediável e predeterminada. No mínimo, parece correto reconhecer que é a percepção transformadora que estabelece a diferença entre matéria bruta e paisagem.", p. 17 e 20 . O termo "marca", usado no texto, tem o significado de expressar a transformação que o homem opera na paisagem natural.

${ }^{30}$ MORENO, Gislaene; HIGA, Tereza Cristina Souza (Org.). Geografia de Mato Grosso: território, sociedade, ambiente. Cuiabá: Entrelinhas, 2005. p. 272.

${ }^{31}$ A região do Cuiabá compreendia as minas do Cuiabá e demais áreas que ficaram conhecidas na historiografia mato-grossense como termo do Cuiabá, mais propriamente o termo da Vila Real do Senhor Bom Jesus do Cuiabá, com flora e fauna típicas do cerrado e pantanal e, segundo o que esclarece Rosa: “o termo era o que chamaríamos hoje de território municipal”. ROSA Carlos Alberto. Mínima..., op. cit., p. 25.
} 
o trabalho escravo dos Cabixi, Paresi, Maimbaré, Bacairi, Guató, Paiaguá, Bororo.

Em 1740 existiam 'mais de dois mil' índios 'administrados', no termo da Vila Real, a população do termo era 'mais ou menos' seis mil pessoas, os índios sendo 35 por cento desse total. Não se sabe ainda quantos viviam na vila. Mas trabalharam na construção do espaço edificado em seu território invadido, moraram nele, percorreram-no de ponta a ponta. ${ }^{32}$

Os índios Paresi, reiteradamente escravizados desde os anos iniciais da expansão e colonização pelo interior da América, foram citados em documentos como trabalhadores de roçados na Vila do Cuiabá e nas terras de São Paulo. ${ }^{33} \mathrm{~A}$ utilização do trabalho indígena "estendeu-se à agricultura, à pecuária e aos serviços domésticos". Os índios Paresi, "com status de colonos, viviam na Vila do Cuiabá, cuja produção excedente era levada para abastecer o mercado local". ${ }^{34}$ Uma fonte setecentista dos anos trinta informa a existência de homens proprietários de índios Paresi na região:

Em virtude de um bando que v. Excelência que aqui mandou lansar o Brigadeiro Regente se tem matriculado os Indios Parecys por esta Provedoria, aonde fazem termo, e dam fiancé aos entregar sendolhes pedidos por Ordem de Sua Magestade para as syas aldeas, quasi todos que há nestas Minas tenho matriculado excepto o Ouvidor que não deu os seus, nem seu irmão athê o prezente náo são poucos os qye possui. ${ }^{35}$

Ainda, haviam índios Paresi deixados como herança quando da morte do Senhor Antonio Roiz de Mattos:

Ha poucos dias morreu nestas Minas hum homem a bem testado chamado Antonio Roiz de Mattos, e pellos auzentes se lhe tomou conta de seys bens entre os quais huve eu q. andar em praça hu.m citio com três índios Parecizes, quando a V. Excelencia lhe paressa justo que morrendo alguma pessoa a bem testada, tendo semelhante gentio se tome conta delle por esta Provedoria, com ordem de Vossa Excelencia o farey entregandose a pessoa muyto capaz, fa-

\footnotetext{
${ }^{32}$ ROSA, Carlos Rosa. O urbano..., op. cit., p. 37.

${ }^{34}$ ASSIS, Evaldo de. Op. cit., p. 89.

${ }^{35}$ CÓPIA DE CARTA...., op. cit., p. 58.

${ }^{33}$ CANOVA, Loiva. Os doces bárbaros: imagens dos índios Paresi no contexto da conquista portuguesa em Mato Grosso (1719-1757). 2003. 113 f. Dissertação (Mestrado em História) - Instituto de Ciências Humanas e Sociais, Universidade Federal de Mato Grosso, Cuiabá, 2003. 
zendo este termo, e dando fiança aos entregar quando V. Excelencia mande se entregarem nas Aldeyas de S. Magestade que sempre me paresse mais quoarente [?] do que os auzentes tomarem conta delles, e facão nisto conveniências com gente forra e liberta, com tem feito o Ouvidor que se náo serve com outra gente. $^{36}$

Nos anos quarenta dos mil e setecentos, índios de diferentes nações estavam na Vila e participavam dos cotidianos festivos e dos cerimoniais católicos. A informação é confirmada em carta assinada pelos oficiais da Câmara da Vila de Cuiabá, quando camaristas relatam ao rei Dom João $\mathrm{V}$ as despesas com o festejo da procissão do Corpo do filho do Deus cristão. Para o ritual, os funcionários diziam necessitar de "cera" para o uso de todos os moradores, a fim de iluminar as ruas e para bem impressionar os índios que assistiriam ao cortejo. O ritual cristão, se bem paramentado, justificavam os camaristas, traria mais índios para o batismo.

Não Sô nas festas, e procissoes que a lei determina[?] Se fação, mas tambem, e principalmente[?] na do Corpo de Deus toda da real proteção[?] de V. Mag. ${ }^{\text {de }}$ Se practica nesta Villa a grande[?] indecencia de quaze hir Sem Luzes, porque Como[?] ainda Se não achão restabelecidas as poucas[?] Irmandades que nella há, e [ileg. + - 2 pal.] rendas[?] para as despezas, Supposto que acompanhe[?] as procissoes não tem Cera com que o fação; ao[?] que me parece justo que o pio, e Catholico Zelo de V. Mag. ${ }^{\text {de }}$ não permitta o concorra[?] com as Luzes neceSsarias aSim as Irmandades Como a todas as pessoas que tiverem Servido nesta Camera obrigadas a acompanhar as ditas procissoes, porque Se nas mais povoações deste Brazil, aSim Se esta practicando; Com[?] muito maior rezão Se deve observar nesta[?] Comarca, onde a immensidade de gentios[?] de varias nascões estâ attento ao nosso Culto[?] divino, e lhes Servirâ de maior edeficação[?] toda a magnificencia, Consiliando os animos para Com mais fervor deixarem os Seus gentilicos ritos, e Se inclinarem a receber o Santo baptismo. O que aSim[?] esperamos na real grandeza de V. Mag. ${ }^{\text {de }}$ e que determine aos Corregedores Levem em[?] Conta esta despeza aos Procuradores da Camera, pela qual esperamos em Deus[?] Seja Servido duplicar as rendas della no[?] maior augmento destes vastos dominios[?] [f. 1v] Dominios de V. Mag. ${ }^{\text {de }}$, que em tudo mandarâ o que for Servido. ${ }^{37}$

\footnotetext{
${ }^{36}$ idem.
}

${ }^{37}$ CARTA dos camaristas da Vila de Cuiabá (Domingos Leme da S.a[?], Christovão de Magalhais Morais, Fran. ${ }^{\text {co }}$ Ribr. $^{0}$ e Moraes, Dionizio Fellix de carvalho e Luis de Araujo Coura) ao rei Dom Jõao V. Vila de Cuiabá, 22 jun. 1748. Arquivo Histórico Ultramarino, Mato Grosso. Projeto Res- 
Neste caso, os funcionários da Câmara mostraram-se ocupados em utilizar os recursos de sedução por meio dos paramentos que ornavam a procissão e do festejo, com a intenção de convencer os índios a adotarem as novas práticas religosas trazidas pelos colonizadores. As práticas de conversão ao Cristianismo usadas pelos missionários faziam-se, muitas vezes, pela oralidade, pelas preleções verbais ou pelas encenações gestuais e religiosas, empregadas "para melhor atrair a atenção dos seus ouvintes". ${ }^{38}$

Passados três anos da solicitação dos funcionários da Câmara feita ao rei para atender aos custos da dramatização ritualística de festejos cristãos, comprovando o enredo da presença indígena na Vila, tem-se outro relato interessante do Governador da Capitania. Segundo Antônio Rolim de Moura, para assim justificar a necessidade da fundação de uma missão na Serra Acima, ou na Chapada do Guimarães, como é mais comumente denominada, destacou os maus-tratos e as más condições em que viviam os índios sob a administração dos moradores da Vila do Cuiabá.

Neste principio Sempre ella ha de Ser mayor porque he tal o dezemparo em que estes Mizaraves Viviam na mam dos Seus administradores que a Mayor parte andavam quazi inteiramente nus e adoecendo os deix[?] morrer Sem assistencia pello que aos que Se tem vindo recolher foy e he necessario acodirlhe a muytos com aLguma cobertura e curalos das queixas que padeciam Sem remedio que principalmente este anno tem Sido muyto geraes $[\ldots] .^{39}$

Embora se tenha aqui um discurso enaltecedor da boa conduta diante de seus pares, do bom governante, do homem cumpridor das responsabilidades a ele atribuídas a mando da Rainha de Portugal, Mariana d'Áustria", ${ }^{40}$ esposa do

gate. Caixa 4, doc. n. 234.

${ }^{38}$ Sobre o assunto da atuação dos missionários, ler: ALMEIDA, Maria Regina Celestino. Os índios na História do Brasil. Rio de Janeiro: FGV, 2010. p. 95.

${ }^{39}$ CORRESPONDÊNCIA enviada pelo Governador e Capitão-General da capitania de Mato Grosso Antônio Rolim de Moura para o Rei D. José. Vila Real do Senhor Bom Jesus do Cuiabá, 11 jul. 1751. Arquivo Histórico Ultramarino, Mato Grosso. Projeto Resgate. Caixa 6, doc. n. 355. Este documento também é lido na: CÓPIA da carta de Antônio Rolim de Moura para Sua Majestade D. José I. Vila Real do Senhor Bom Jesus do Cuiabá, 11 jul. 1751. Arquivo Público do Estado de Mato Grosso. Livro de Registro de Provisões Reais, Patentes, Cartas e Bandos. Governo de Antônio Rolim de Moura e Luiz Pinto de Souza Coutinho. Manuscrito, Livro C-04, Estante 1, Doc. 193, [f. 13-13v].

${ }^{40}$ Para estudo desse assunto, ver: INSTRUÇÕES dadas pela Rainha ao Governador da capitania de 
adoentado rei D. João V, é bem verdade que os índios viviam no espaço da Vila em condições nada dignificantes.

Além de escrever a respeito dos maus-tratos dos administradores, construindo-se um bom sertanista, o Governador relata a dizimação dos índios, alçados pelos interesses de preadores sertanistas:

Todo este districto da Cuyabá acharam os primeiros Sertanistas coalhado de Gentio de que hoje não ha mais do que huns pequenos restos e os que Se achão na mam dos administradores que me parece Não chegaram a SeisCentos. Precizamente assim havia de Ser porque desde que estas terras Se descobriram Sempre os Sirtanistas andaram em busca delles. Chegando a aLguma aLdea depois de a renderem a poder de fogo metiam em correntes as molheres e homés que podiam terlhe Serventia ou pera a comcupicencia ou pera o Serviço das roças e o que hera inutil passavam a cotelo ordenariamente Como tambem aos que no caminho mostravam qualquer repugnancia. Recolhidos a Suas Cazas os vendiam Como pretos chegando a rematalos publicamente ate o tempo de João Gonçalves Pereira que Servio de Ouvidor e pos nisso algum Cobro porem ficaram Sem [f. 3v] pre athe a minha vinda fazendo as mesmas vendas ou ocultas ou paliadas. ALem disto os tratavam Com Sumo rigor ao mesmo tempo que nas Suas doenças os deichavam morrer ao dezemparo Cuidando tam pouco da Sua doutrina que huma grande parte dos que ainda ha estam por bautizar. $^{41}$

A narrativa reforça informações sobre o comércio de homens setecentistas interessados na venda de nativos em diferentes regiões da colônia. Essas práticas de escravização e posterior comércio eram mais eficazes quando os índios eram vistos como mansos, fiéis, dóceis e amigos. Imagens que ganhavam importância e representavam um campo de atuação, maiormente porque as informações circulavam nos espaços do poder colonial e metropolitano. Imagens construídas que fizeram dos índios alvos especiais na direção dos interesses dos agentes coloniais e colonizadores, ora para escravizar, ora para aldear, ora para matar.

Mato Grosso, D. Antônio Rolim de Moura, 19 jan. 1749. In: MOURA, Carlos Francisco. D. Antônio Rolim de Moura, Primeiro Conde de Azambuja: biografia. Cuiabá: EdUFMT, 1982. (Coleção Documentos Ibéricos, Série Capitães-Generais, 1), p. 127-137. INSTRUÇÃO Real. Lisboa, 19 jan. 1749, p. 128. Foi localizada em Cuiabá uma cópia manuscrita [a parte inicial está danificada, faltam os oito primeiros considerandos] da INSTRUÇÃO REAL enviada pela rainha de Portugal ao Governador e Capitão-General da capitania de Mato Grosso Antônio Rolim de Moura. Lisboa, 19 jan. 1749. Instituto Histórico e Geográfico de Mato Grosso. Pasta 23, n. 1391.

${ }^{41}$ CORRESPONDÊNCIA..., op. cit., 1751. 
Na Repartição do Cuiabá, além de os índios serem persistentemente caçados por sertanistas com a intenção de escravizá-los, foram também objeto de interesse dos agentes missionários e do Governador Antônio Rolim de Moura, com o fito de os reduzirem a um sistema de aldeamento.

Depois de se estabelecer na Vila Real do Senhor Bom Jesus do Cuiabá, em julho de 1751, Rolim de Moura segue a orientação régia de encarregar-se da fundação de um aldeamento que estivesse sob a administração de um missionário da Companhia de Jesus no Distrito do Cuiabá, o jesuíta Estêvão de Castro. O padre Estêvão de Castro foi o responsável pela organização de uma missão jesuítica em Santana do Sacramento, atual Chapada dos Guimarães. ${ }^{42}$

O lugar escolhido para a fundação da missão de Santana foi ocupado oficialmente pela ação colonizadora portuguesa nos anos vinte do setecentos, quando o Capitão-General da capitania de São Paulo, Rodrigo César de Menezes, doou a Carta de Sesmaria ao Tenente Coronel Antônio de Almeida Lara, paulista de Sorocaba, em 1726.

A propósito da escolha do lugar da missão, tem-se que os argumentos apresentados pelo missionário Estêvão de Castro tinham caráter elucidativo e avaliava o local ponto por ponto, enfatizando o ambiente como o melhor lugar para a instalação da missão. O primeiro motivo apresentado foi o lugar da Serra Acima estar livre de doenças, ser de fácil acesso e pela proximidade da Vila do Cuiabá:

Pelo Reverendíssimo Padre Estevão foi dito o seguinte: Eu que a vinte e três meses cuido do Cargo dos índios para que Deus me chamou, e a minha religião me entregou, e havendo quatro meses que estou no Cuiabá, em cujo distrito ordena Sua Majestade, se funde a nova aldeia para os índios que estão dispersos e maltratados por alguns moradores, não tenho achado sítio mais cômodo que o da Chapada, distando nove léguas desta Vila para o nascente, pelas razões seguintes. Primeira por ser o sítio mais saudável deste distrito por voto de todos, mostrando-os experiência, que estando ardendo este presente ano todo o distrito do Cuiabá em doenças, vi eu que só no sítio da chapada não havia doença alguma que se pudesse chamar epidêmica $[\ldots]{ }^{43}$

\footnotetext{
${ }^{42}$ CÓPIA DO TERMO DA JUNTA, que fez para a determinação do sítio em que se devia fazer para aldeia dos Padres da Missão. Vila Real do Senhor Bom Jesus do Cuiabá, 9 maio 1751. Arquivo Público do Estado de Mato Grosso. Livro de Registro de Termos de Juntas, Petições e Cartas Expedidas (1751-1808). Governo de Antônio Rolim de Moura e Caetano Pinto M. Montenegro. Manuscrito, Livro C-08, Estante 1, [f. 6-14].
}

${ }^{43}$ Idem. 
Para o padre Estevão de Castro, poderia haver investimentos em roças, pois ali existiam matas cuja extensão ele associou à capacidade nutricional do solo. A fertilidade da terra, segundo item avaliado, foi projetada a partir do indicador da existência de matas, "que dizem continuar por três dias de viagem, circunstância muito elogiável para roçarias". ${ }^{44}$ Nos estudos que tratam da legislação indigenista, há informação de que a Coroa ocupava-se em legislar por meio de Cartas Régias, instruções reservadas aos colonizadores. A respeito das terras para o aldeamento destinado aos índios, deveriam levar em consideração as dimensões, a produtividade para o plantio das roças e rio para as pescarias. ${ }^{45}$

Ainda sobre o assunto da escolha do lugar da aldeia, apesar de não existirem rios navegáveis, havia recursos fluviais com peixes que, mesmo no tempo das chuvas e das enchentes, os índios da região, os Bororo, usavam dos ribeirões para a atividade da pescaria. $\mathrm{O}$ terceiro motivo era o de que

ainda que não tem rio navegável, tem contudo ribeirões em que se acha peixe, e se tem pescado em abundância, como o que experimentei na quaresma deste presente ano, que sendo tempo de enchentes no Cuiabá, e por isso [ilegível] me trouxeram uns índios Bororo os dezoito peixes de competente grandiosa, os quais comemos frescos neste dia, e com sal em seis dias seguintes $[\ldots]{ }^{46}$

O aldeamento construído na Chapada dos Guimarães teve por objetivo a realização do projeto colonial, pois garantiria a conversão, a ocupação do território, sua defesa e constante reserva de mão de obra para o desenvolvimento econômico da frente colonizadora nos tempos em que se convencionou chamar de mercantilismo.

Segundo Maria Regina Celestino de Almeida, as aldeias foram "construídas para atender a interesses diversos". Seus idealizadores e fundadores nem sempre eram religiosos. Os grupos indígenas nas aldeias eram variados e estabeleciam, como também influenciavam, diferentes relações com as sociedades envolventes. Nelas, ocorriam processos de reelaborações identitárias, pois a política do

${ }^{44}$ Idem.

${ }^{45}$ PERRONE-MOISÉS, Beatriz. Índios livres e índios escravos: os princípios da legislação indigenista do período colonial (século XVI a XVIII). In: CUNHA, Manuela Carneiro da (Org.). História dos índios no Brasil. São Paulo: Companhia das Letras; Secretaria Municipal de Cultura; FAPESP, 1998. p. 118.

${ }^{46}$ CÓPIA DO TERMO DA JUNTA..., citado. 
aldeamento indígena tinha por intuito transformar os índios em súditos cristãos. Representavam também novas territorializações, visto que as aldeias constituíam espaços demarcados por elementos de fora, cuja experiência interativa entre índios de distintas nações e missionários possibilitavam novas elaborações culturais e, portanto, assimilacionistas, tanto dos que projetavam a política quanto daqueles que as negociavam, ou a ela eram submetidos (no caso dos índios). Nesse processo, os índios se transformavam ou eram transformados, necessariamente, conforme os padrões jesuítas, por meio de proibições de seus cultos e das suas tradições, que poderiam ser milenares. A política missionária nas aldeias atuava de modo a cumprir discriminações e preconceitos, propondo sobretudo a ideia de catequisar com intenções de promover benefícios de dominação colonial e religiosa. ${ }^{47}$

A política de aldear índios era destinada especialmente aos índios bons, aos amigos ou aliados. Com os índios inimigos, a prática dos conquistadores era a guerra justa, qual seja, o extermínio dos contumazes inimigos resistentes à colonização por meio do uso de armas de fogo. De modo geral, a prática de eliminar os índios considerados inimigos, pestilentos, infiéis, traiçoeiros, "bixos", como escreveu o Provedor da Fazenda Real das minas do Cuyaba Thomé de Gouvea e Saâ Queiroga, foi recorrente no Cuiabá, notadamente relativa aos da nação Paiaguá.

Os índios Paiaguá, por terem seus territórios na região que vinha sendo dominada pelos colonizadores, demandavam, da parte do governo e de moradores do Cuiabá, políticas e investimentos para submeter-lhes à derrota e forçar o seu silêncio.

Dos registros oficiais locais a propósito dos ataques da nação Paiaguá, as notícias relatam que foram iniciadas ações de guerra contra expedições monçoeiras no ano de 1725. Esses índios investiam de maneira inesperada e violenta, "assaltando mercadorias" e destruindo as munições. Conforme relato de Sérgio Buarque de Holanda, em um dos ataques dos Paiaguá contra os monçoeiros, em uma viagem datada de 1725 , de um total de seiscentas pessoas, distribuídas em vinte canoas, só duas se salvaram, um negro e um branco. ${ }^{48}$ Os ataques indígenas

\footnotetext{
${ }^{47}$ ALMEIDA, Maria Regina Celestino. Op. cit., p. 95 a 100.

${ }^{48}$ HOLANDA, Sergio Buarque de. Op. cit., p. 64.
} 
às expedições tornaram-se recorrentes, conforme descrito por José Barbosa de Sá: no ano de 1726, novamente a monção que vinha a Cuiabá foi atacada pelos Paiaguá, e a luta entre os índios e os monçoeiros foi sangrenta. Do combate restaram dois rapazes, que lutaram até as últimas forças. Ao referir-se ao assunto, escreve:

[...] Vindo neste ano monção, junta em uma grande frota, foi assaltada do gentio Paiaguá [...]; com eles embarcaram dois fortes mancebos, que mereciam seus nomes letras de ouro escritas nas asas da Fama [...], naturais da vila de Itu. Cercados [...] do gentio pelas oito horas do dia, pelejaram até as duas da tarde, primeiro com armas de fogo, deixadas estas à espada, rebatendo as lanças dos gentios, arrancando-lhas das mãos e com elas ferindo-os. Perdidos os companheiros e remeiros, mantiveram a peleja eles sós, matando muitos bárbaros e ferindo-os [...], em tal forma que sobre eles caiu todo o ferino poder, até que renderam as vidas a troco das muitas que tiraram $[\ldots] .{ }^{49}$

Os frequentes ataques aos monçoeiros resultavam em mortes e raptos. Informações documentais revelam enfrentamentos desde os anos iniciais da colonização nas minas do Cuiabá, quando os Paiaguá destroçavam completamente a leva de canoeiros. Uma centena de brancos, negros e mestiços morreu na monção do ouvidor Antônio Lanhas Peixoto, em 1730. Nesse episódio, os Paiaguá levaram cerca de dez arrobas de ouro, roupas e armas para comercializarem com os castelhanos em Assunção.

O ataque provocaria a represália oficial, através de expedição armada pelo capitão Antônio Almeida Lara, em Cuiabá, no ano de 1731, numa investida que matou muitos índios e os perseguiu até os arredores de Assunção. Os choques, contudo, prosseguiriam ainda por várias décadas. ${ }^{50}$

A nação Paiaguá, por sua conduta guerreira, foi vista como "inimiga, infiel, selvagem, pestilenta”... Essas são representações dos Paiaguá na Repartição do Cuiabá, conceitos que ganharam visibilidade nos discursos oficiais dos administradores coloniais e da Coroa. Em um discurso oficial da metrópole, datado do ano de 1749, com respeito aos índios Paiaguá, a Rainha mandou fazer ataques

\footnotetext{
${ }^{49} \mathrm{SÁ}$, José Barbosa de. Relação das povoações de Cuiabá e Mato Grosso de seus princípios até os presentes tempos. Cuiabá: EdUFMT; Secretaria de Educação e Cultura, 1975, p. 2. Na obra, Sá descreve a guerra dos moradores da Vila do Cuiabá contra os índios Paiaguá.

${ }^{50}$ SILVA, Valderez Antônio da. Os fantasmas do rio: um estudo sobre a memória das monções no vale do médio Tietê. 2004. Dissertação (Mestrado em História) - Instituto de Filosofia e Ciências Humanas, Universidade Estadual de Campinas, Campinas, 2004. p. 49.
} 
"às suas ilhas", que ficavam nas águas do Rio Paraguai. Ainda consta que "aos Governadores de São Paulo" se ordenou que "mandassem alguns bergantins armados com gente de ordenanças para castigar os insultos d'aqueles bárbaros, e segurar a navegação dos ditos comboios". Com respeito às ações políticas destinadas aos índios Paiaguá, as orientações da Rainha são de rigor e de atenção com relação àquelas orientações dirigidas ao governante:

Confio do vosso zelo atendais a preservar os navegantes e vizinhos do dito rio do susto d'aquele gentio, e quando exaustos todos os meios de persuasão e de brandura, não possais conseguir que desista das suas hostilidades, procurareis eficazmente reduzi-los com castigo a viverem racionalmente. E si para isto necessitardes de alguma cousa que faltem n'aquele sertão, o avisareis pelo dito conselho, para se darem as providencias convenientes. ${ }^{51}$

A imagem da ameaça e do horror também ganhou espaço nos escritos do oficial português Antônio Rolim de Moura. Em representações do perigo e do medo, apresentou os índios com aspectos indesejáveis, definiu-os como irracionais e capazes de tornar a vida do colonizador um martírio. Por serem tão diferentes, tão resistentes, justificava-se a prática da "guerra justa", ${ }^{52}$ ou seja, era defensor da luta armada, que foi viabilizada por meio da organização de grupos de homens moradores da Vila do Cuiabá.

Mesmo o Governador estando no Guaporé, mantinha-se informado sobre a ofensiva dos Paiaguá na Repartição do Cuiabá. Pelo visto, os índios continuavam agindo contra os que andavam pela região do Pantanal. Ele, por sua vez, tomou decisões políticas com o intuito de fazer dos Paiaguá índios com menos "atrevimento":

A vista disto, chegando ao Cuiabá, dei conta a Sua Majestade para que me determinasse o que devia obrar, vendo que o dito Sr. me recomendava também muito evitasse todo o motivo de escândalo aos vassalos d'El Rey de Castella.

\footnotetext{
${ }^{51}$ INSTRUÇÕES dadas pela Rainha ..., op. cit., p. 132.

${ }^{52}$ O Conde de Sarzedas, em 15 de agosto de 1732, publicou um bando aprovando a "guerra justa" aos Paiaguá e a outros grupos ameríndios tidos como inimigos, "através do qual abria alistamento e prometia aos participantes da luta a repartição de cativos, além de patente de oficial aos mais capazes". CANAVARROS, Otávio. O poder metropolitano em Cuiabá (1727-1752). Cuiabá: EdUFMT, 2004. p. 255 e CHAVES, Otávio Ribeiro. Política de povoamento e a constituição da fronteira oeste do império português: a capitania de Mato Grosso na segunda metade do século XVIII. 2008. Tese (Doutorado em História) - Universidade Federal do Paraná, Curitiba, 2008. p. 52.
} 
Naquele tempo, nem o poder nem a ousadia era tanta no gentio quebrantado ainda da última derrota que havia tido; porém agora me veio parte do Cuiabá, que ele havia chegado com vinte e seis canoas a Figueira, dois dias de viagem até o porto da vila, e que ali matou um pescador e lhe levou quatro índios e depois encontrando-se com uma canoa em que iam três brancos e outros escravos, dois destes se haviam retirado, e dos mais se não sabia. Nestes termos me resolvi escrever ao Governador da Assumpção a carta, cuja cópia remeto inclusa, e enquanto não chega a sua resposta ou resolução de Sua Majestade determino mandar canoas de guarda costa para desinfestarem os rios, principalmente o Cuiabá, e ver juntamente se podem alcançar ocasião de bater o gentio, e refrear-lhe assim mais o seu demasiado atrevimento. ${ }^{53}$

Em algumas fontes, Rolim de Moura descreveu como atributos dos Paiaguá a vileza e a insolência, definindo-os como "pestilentos, hostis e violentos", em outras passagens, os índios Paiaguá eram "gentios nossos inimigos". ${ }^{54}$ A política de Rolim de Moura em relação aos Paiaguá foi de austeridade: como representante das forças militares de Portugal e principal autoridade na Capitania, agiu para impulsionar sua destruição, e suas representações animaram ações para tal fim.

Em sua análise, os Paiaguá deveriam ser tratados com severidade, pois foram os que mais trabalho deram aos colonos da Vila:

Exmo. Sr. o gentio Paiaguá inimigo antigo e novo meu que depois de uma grande vantagem que sobre ele tivemos andara mais abatido, agora torna outra vez a afoitar-se, e são repetidos os assaltos com que tem infestado os rios que servem de comunicação a este governo com os portos de mar; pelo que me vejo precisado a procurar os meios de pôr fim as suas hostilidades, e como este não poderá conseguir-se sem atacar nos seus próprios alojamentos, e os principais deles se acham não somente dentro da demarcação determinada pelo novo Tratado, pertencente a Sua Majestade Católica, mas muito vizinho à Cidade da Assumpção, não quis dar a execução este projeto sem participá-lo a V. Exa. e

${ }^{53}$ OFÍCIO do [Governador e Capitão-General da capitania de Mato Grosso] Antônio Rolim de Moura ao [Secretário de Estado da Marinha e Ultramar] Diogo de Mendonça da Corte Real sobre a ordem de reduzir o gentio Paiaguá por bem ou por meio das armas. Vila Bela da Santíssima Trindade, 28 jul. 1753. Arquivo Histórico Ultramarino, Mato Grosso. Projeto Resgate. Caixa 7 , doc. n. 433. (grifo nosso).

${ }^{54}$ RELAÇÃO da viagem que fez o Conde de Azambuja da cidade de São Paulo para a Vila do Cuiabá no ano de 1751. In: PAIVA, Ana Mesquita Martins de et al. (Org.) D. Antônio Rolim de Moura: primeiro Conde de Azambuja. (Correspondências). Cuiabá: EdUFMT, 1982. v. 1, p. 18. 
pedir-lhe o Seu beneplácito, assim pela atenção que V. Exa. merece pelo Seu lugar e parte, como pela que meu amo me manda ter com tudo que diz respeito a Sua Majestade Católica. ${ }^{55}$

Rolim de Moura escreve ainda dos índios Paiaguá, tendo como amparo aos seus argumentos as instruções da Rainha, que prescreviam morte à nação. O enfrentamento armado foi argumento bastante difundido na lida com a nação. Avaliados na impossibilidade de transformá-los em seres racionais, e diante da constatação da ausência de virtudes domesticáveis, a solução seria sua destruição:

Nas minhas Instruções me ordena Sua Majestade que não podendo acabar por bem com o gentio Paiaguá se abstenha de nos fazer hostilidades que costuma, o reduza a isso pelo meio de armas. O primeiro é impossível por ser aquele gentio bárbaro, e sem fidelidade, da sorte, que ainda quando se pudesse fazer alguma convenção, ficaríamos com ela tão seguros, como não a havendo. $\mathrm{O}$ segundo também parece impraticável, sem serem atacados nos seus próprios alojamentos, os quais estão muito dentro da demarcação pertencente à Castela nas vizinhanças da Cidade de Assunção; porque ainda que se surpreenda nos nossos rios algum corpo deles, nunca essa ação termina a guerra, somente a moderará por algum tempo. Porém esta mesma surpresa tem grande dificuldade porque este gentio não passa para os nossos rios, se não quando as suas margens estão alagadas, e por elas é que marcha, o que as nossas canoas não podem fazer com a mesma facilidade assim pelo seu tamanho, como por falta de conhecimento das veredas nos nossos pilotos, cuja circunstância lhe dá uma grande vantagem sobre nós, que é observar-nos sempre, e atacar-nos só quando tem partido. ${ }^{56}$

Esse excerto demonstra que o Governador alertava da necessidade da frota para acompanhar as canoas que poderiam ser atacadas pelos Paiaguá. Desde os primeiros escritos de sertanistas e outros agentes coloniais, há registros de narrativas que expõem os contumazes ataques desta nação. É certo que, por ocasião da derrota na guerra contra os invasores de seus territórios, os Paiaguá se tornavam menos hostis, apesar de ser uma situação circunstancial. As vozes, com o fim de atacá-los, bem como sua hostilidade, são também proferidas por Rolim de Moura, que determinava a execução de projetos que "desinfestassem a comunicação dos rios que levavam aos portos do mar".

\footnotetext{
${ }^{55}$ OFÍCIO do [Governador..., citado.

${ }^{56}$ Idem.
} 
De outro, os Paiaguá foram assimilados à política de aldeamento na missão de Santa Ana, localizada Serra Acima. Esses eram informantes sobre assuntos relacionados aos espanhóis. Sabe-se que a nação Paiaguá estabeleceu política de aliança com os vizinhos fronteiriços:

[...] Tendo eu notícia de que um Paiaguá casado fora com toda a sua família buscar de paz o sítio de Camapuã; o mandei vir para o Cuiabá, e dali passá-lo para a aldeia de Santa Ana vizinha àquela Vila; e lhe mandei fazer perguntas sobre a situação das povoações daquele gentio, e sobre o trato que tem com os espanhóis pela suspeita que há nesta Capitania de que eles os ajudam a fazer-nos a guerra; a qual é fundada em se lhe haverem achado por várias vezes lanças [ilegível] choupas de ferro muito bem tiradas; e argolas de bronze, com pontas nos seus porretes que são as armas de que se servem mais ordinariamente; e de uma causa e outra se acham na minha mão amostras que foram apanhadas já no meu tempo pelo Alferes de Dragões em um dos comboios das Canoas de Comércio. E como os ditos Paiaguás se não sabe que tenham forjas, antes é uma casta de gentio volante, e que não faz permanência por muito tempo em uma parte parece sem dúvida que só lhe podem vir as duas armas do comércio que tem com os espanhóis seus vizinhos da cidade de Assumpção e mais povoações que há para aquela parte sendo pois perguntado o do Paiaguá, e as mais pessoas da sua família. ${ }^{57}$

Na história do Mato Grosso setecentista, foram os índios Paiaguá os que mais resistiram ao poder do colonizador. Nos múltiplos registros em documentos escritos por Antônio Rolim de Moura, aparecem dados dos arriscados ataques desta nação. Esses índios foram descritos como destros na arte da navegação; chamados de corsos, viviam ao longo do Rio Paraguai, eram nômades, moravam nas canoas, sobreviviam dos recursos do Pantanal e aprenderam a importância do comércio com os assuncenhos. As práticas comerciais assimiladas pelos Paiaguá, como forma de resistência e negociação com os inimigos portugueses, representam o processo interativo de aprendizado entre os homens do empreendimento colonizador e os nativos.

Para assegurar a construção do projeto colonial e garantir interesses individuais, colonos e colonizadores contaram com o trabalho dos índios em diversas

${ }^{57}$ OFÍCIO do [Governador e Capitão-General da capitania de Mato Grosso] Antônio Rolim de Moura ao [Secretário de Estado da Marinha e Ultramar] Diogo de Mendonça da Corte Real. Vila Bela da Santíssima Trindade, 26 jun. 1756. Arquivo Histórico Ultramarino, Mato Grosso. Projeto Resgate. Caixa 8, doc. n. 518. 
atividades. As histórias que moveram recursos privados dos homens da Vila do Cuiabá não se restringem à guerra aos índios Paiaguá. As variantes iam da solicitação de investimentos da metrópole para promoção à vida cristã, como também narrativas que denunciavam a condição difícil daqueles que estavam reclusos na cadeia da Vila,

A Câmara da Vila do Cuiabá me tem representado do que a cadeia dela se acha sempre cheia de presos, os quais por muito passam grandes misérias, e que podem também prejudicar ao comum, por poderem originar-se dali epidemias, que entrem a lavrar pela terra. Duas são as causas disto, a primeira é correrem somente os livramentos dos que têm que gastar, e os que são pobres se eternizam na prisão, a outra o não haver nesta capitania a ordem para se sentenciarem em junta de justiça até pena de morte de pretos, mulatos e carijós [.....$^{58}$

A presença de pretos, mulatos e carijós (índios cristianizados) na cadeia pública da Vila do Cuiabá é uma mostra da sociedade desigual, racista e preconceituosa, construída nos tempos iniciais da colonização. Esses ocupavam os espaços da trangressão e, neste caso, se fosse possível, Antônio Rolim de Moura os executaria com a pena de morte, pondo fim aos custos de manutenção dos transgressores do inapropriado local: a cadeia. Sua intenção de relatar a superlotação da prisão ocupada pelos pobres do local e os problemas epidêmicos dali gerados, poderiam se alastrar pela Vila e seus arrredores, justificando, desse modo, a condenação à pena de morte.

$\mathrm{Na}$ Vila do Cuiabá, além de índios reclusos merecedores da pena de morte, de índios para serem convencidos ao batismo, de índios doentes e maltrapilhos, vivendo sob a tutela de administradores, havia índios que eram donos de si, possuidores de escravo e venda.

Nestas minas [do Mato Grosso] se acha um índio Pareci casado, que vive sobre si com roça, e criações, sem ter, nem necessitar de administração de ninguém. No Cuiabá também há outro, que não só vive sobre si, mas tem um escravo seu em uma venda por sua conta. ${ }^{59}$

\footnotetext{
${ }^{58}$ CARTA enviada por Antônio Rolim de Moura a Sua Majestade Dom José I. Vila Bela da Santíssima Trindade, 3 fev. 1755. In: PAIVA, Ana Mesquita Martins de et al. (Org.) D. Antônio Rolim de Moura: primeiro Conde de Azambuja. (Correspondências). Cuiabá: EdUFMT, 1982. v. 2, p. 59.

${ }^{59}$ CARTA enviada por Antônio Rolim de Moura a Francisco Xavier de Mendonça Furtado. Vila Bela da Santíssima Trindade, 14 dez. 1758. In: PAIVA, Ana Mesquita Martins de et al. (Org.). D. Antônio Rolim de Moura: primeiro Conde de Azambuja. (Correspondências). Cuiabá: EdUFMT, 1982, v. 3, p. 203.
} 
Os assuntos contidos na citação podem ser problematizados à luz do "Directório, que se deve observar nas povoações dos índios do Pará, e Maranhão, em quanto Sua Magestade não mandar o contrario". ${ }^{60}$ Esse conjunto de leis representa um documento jurídico que regulamentou na América portuguesa as ações dirigidas aos índios entre os anos de 1758 e 1798.

Os conteúdos da política assimilacionista, tratados particularmente na administração pombalina, necessitam de maiores estudos na historiografia regional, de maneira especial, diga-se aqui das questões referentes à temática indígena, após a publicação do Directório. Por ora, o intento deste texto foi mostrar fragmentos da presença indígena na região do Cuiabá, com o sentido político de alertar a sociedade da contribuição histórica desses povos e do respeito que merecem nas relações estatais e privadas, muitas vezes estabelecidas de forma autoritária. Maiormente, aviltante dos direitos à vida de povos que construíram patrimônios culturais à nação e, em particular, ao Estado de Mato Grosso.

Com o intuito de finalizar tão variado campo de discussão, são citadas as explicações de Maria Regina Celestino de Almeida,

Os povos indígenas tiveram participação essencial nos processos de conquista e colonização em todas as regiões da América. Na condição de aliados ou inimigos, eles desempenharam importantes e variados papéis na construção das sociedades coloniais e pós-coloniais. Foram diferentes grupos nativos do continente americano de etnias, línguas e culturas diversas que receberam os europeus das formas mais variadas e foram todos, por eles, chamados índios. Eram, em sua grande maioria, povos guerreiros, e suas guerras e histórias se entrelaçaram, desde o século XVI, com as guerras e histórias dos colonizadores, contribuindo para delinear seus rumos. ${ }^{61}$

${ }^{60}$ DIRECTÓRIO, que se deve observar nas povoações dos índios do Pará, e Maranhão, em quanto Sua Magestade não mandar o contrario. Lisboa: Officina de Miguel Rodrigues, 1758.

${ }^{61}$ ALMEIDA, Maria Regina Celestino. Op. cit. , p. 7. 